\title{
Paideusis
}

\section{A Tribute to LeRoi Daniels: A Philosopher for All Seasons}

\section{Donald Cochrane}

Volume 19, Number 2, 2010

URI: https://id.erudit.org/iderudit/1071922ar

DOI: https://doi.org/10.7202/1071922ar

See table of contents

Publisher(s)

Canadian Philosophy of Education Society

ISSN

0838-4517 (print)

1916-0348 (digital)

Explore this journal

Cite this document

Cochrane, D. (2010). A Tribute to LeRoi Daniels: A Philosopher for All Seasons.

Paideusis, 19(2), 61-68. https://doi.org/10.7202/1071922ar

(c) Donald Cochrane, 2010

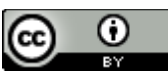

This document is protected by copyright law. Use of the services of Erudit (including reproduction) is subject to its terms and conditions, which can be viewed online.

https://apropos.erudit.org/en/users/policy-on-use/
This article is disseminated and preserved by Érudit.

Érudit is a non-profit inter-university consortium of the Université de Montréal, Université Laval, and the Université du Québec à Montréal. Its mission is to promote and disseminate research.

https://www.erudit.org/en/ 


\section{A Tribute to LeRoi Daniels: A Philosopher for All Seasons}

DONALD COCHRANE
University of Saskatchewan

Visiting Roi on Wednesday evenings became a regular feature of my weeks in Vancouver over the winter. His health had been declining steadily since January so that eventually elementary conversation became impossible. Still, in appearance and outward attitude he remained recognizably Roi. At one point during my last visit, he was experiencing a high degree of agitation and wanted desperately to verbalize it. Finally, he let fly a very audible profanity and sank back into his chair. A little later, he became restless again. One of his caregivers and I lifted him to his feet to take him for a walk across the room. Perhaps not liking all the assistance he was being given but needed, he dug his elbow into my ribs! Assertive to the end! That was our Roi. He died a week later.

Roi was born to LeRoi and Jean Daniels in Calgary at the beginning of the Depression. His father, a quiet man, was a school superintendent. From him, Roi acquired a life-long commitment to education. Roi told me that his mother Jean was the direct one and could be blunt at times-an attribute he inherited! Both were very generous in helping him undertake his university education.

After a year as an undergraduate at Calgary's Mount Royal College in 1950, Roi headed for Montana State University to study journalism. He thought the life of a reporter would be glamorous, but quickly discovered that much of it would be drudgery! He returned to Canada within a year and enrolled in the University of British Columbia graduating with a B.A. in 1953 followed immediately with a one-year teacher training certificate. Over the next ten years, he accepted positions as a teacher and vice-principal in Dawson Creek, a teacher in Nanaimo, and a principal in Kelowna. For five of those years, he chaired the British Columbia Teachers Federation's Research Committee. While in the classroom, Roi promoted research into teaching and learning; later when engaged in research in philosophy of education, the classroom remained a central focus of his attention.

Roi's move to philosophy was aided by "many profitable discussions with Kenneth Argue". ${ }^{1}$ His studies were undertaken in the philosophy department at University of British Columbia (UBC) and it is typical of Roi that his committee would consist of heavy hitters. ${ }^{2}$ Roi set himself the task of figuring

\footnotetext{
${ }^{1}$ From a personal conversation with Roi. Dr. Kenneth Argue (University of Alberta, B.A., 1931; University of Oxford, M.A., 1936; and Columbia University, Ph.D., 1940) was a distinguished member of the Faculty of Education at University of British Columbia (UBC) from 1946 to 1974 . He would be described now as a "generalist" with interests in philosophy and intellectual history. He was aware of new currents in philosophy of education having spent a sabbatical at the Institute of Education University of London in 1962-1963. We know that by 1964 he was using material by Scheffler, O'Connor, Hirst, Peters, Ayer, Ryle, and others in his graduate seminar in philosophy of education.

2 Roi's supervisor, Barnett Savery, was the head of the department and interested in value theory and aesthetics. His two committee members were Avrum Stroll, a distinguished philosopher and a noted scholar in the fields

(C) Copyright 2010. The author, Donald Cochrane, assigns to Paideusis the right of first publication and educational and non-profit institutions a non-exclusive license to use this document for personal use and in courses of instruction provided that the article is used in full and this copyright statement is reproduced. Any other usage is probibited without the express permission of the author.
} 
out how philosophy should be undertaken given the sterility of the "isms" approach. In particular, it was his intention "to outline some of the leading principles of method employed by analytic philosophers and by 'educational philosophers' in order to compare the two and ... to attempt to apply some of the methods of the former group to the work of the latter group." 3 In the "isms" approach (realism, idealism, pragmatism), the leading principle "consist[ed] of the deduction of statements about education from statements in 'regular' philosophy". ${ }^{4}$ It was claimed that the differences in pedagogy among the adherents could be attributed to different positions in their starting philosophy. Breathing the early optimism of the analytic movement, Roi thought the first task of the philosopher of education was to "seek the solution to, or the elimination of, philosophical problems by a study of the way we use and misuse our language." 5 Employing the tools of analysis, ${ }^{6}$ Roi demonstrated that traditional philosophy of education rested on "pseudo-science" (for which read "metaphysics"). Their theories were, he argued, "rather lengthy examples of one type of logical fallacy known as "begging the question"."' He concluded that traditional philosophy of education had been "primarily a form of ethical philosophy". Throughout his career, Roi agreed with Broudy, Ulich, Dewey, and Horne on the central role of ethics in educational judgments and decisions, but parted company with them over how they should be justified. It was clear to Roi that philosophy of education needed to be revamped from the ground up.

In 1965, Roi submitted his resignation as a lecturer at UBC and left to pursue his doctorate the University of Illinois. ${ }^{8}$ Here again, Roi's committee was composed of academics who were either at the top of their game or who were on their way to being so. ${ }^{9}$ His dissertation, "Intervening Variables and Education", 10 might more accurately have been entitled "Hull and Skinner, or How Not to Do Educational Psychology"! His investigation into the epistemological assumptions and conceptual issues of neo-behaviorism in education was very thorough. ${ }^{11}$ Roi concluded that Hull and Skinner had little to

of epistemology, philosophy of language, and twentieth-century analytic philosophy, and R.J. Rowan who later became head of the department.

${ }^{3}$ LeRoi Daniels. "The Leading Principles of Some Philosophers of Education." M.A. thesis, University of British Columbia, 1963. 1.

${ }^{4}$ Ibid., Abstract.

${ }^{5}$ Ibid., 94.

${ }^{6}$ Roi drew on the work of A.J. Ayer, G.J. Warnock, Gilbert Ryle, P.F. Strawson, Ludwig Wittgenstein, John Hospers, and Anthony Flew.

${ }^{7}$ Ibid., 60.

${ }^{8}$ From The President's Report, University of British Columbia, 1964-65. In 1964-1965, Charles Brauner, Jerrold Coombs, and Murray Elliott were appointed to the Faculty of Education at UBC. They would become close colleagues and friends of Roi on his return.

9 Roi's supervisor was the noted philosopher of education B. ("Bunnie") Othanel Smith. His committee, eclectic in their backgrounds, consisted of R. Stewart Jones, co-author with Glenn Myers Blair and Ray H. Simpson of Educational Psychology (1962); Harry Tiebout, who was politically very active and interested in Buddhism and A.N. Whitehead; and Harry S. Broudy, one of the leading American philosophers of education in the United States in the latter half of the $20^{\text {th }}$ Century. Despite the fact that Broudy had been one of the targets of criticism in his masters thesis, Roi maintained that his relationship with Broudy was always cordial and positive. Roi also told me that he benefited from "profitable discussions" with two other philosophers of education, Kenneth Conklin and Erwin Johannigmeier. He also offered special thanks to Charles E. Caton who had just published his influential Pbilosophy and Ordinary Language (1963). He also told me about a "bright young philosopher" who was a positive influence on him. This was probably James Wallace who was only twenty-six when he arrived as an assistant professor at UIUC in 1963. His area of interest was largely in ethical and social issues. He went on to have a stellar career, publishing Virtues and Vices (1978), Moral Relevance and Moral Conflict (1988), Ethical Norms, Particular Cases (1996), and Norms and Practices (2009).

${ }^{10}$ LeRoi Daniels. "Intervening Variables and Education.” Diss. University of Illinois, 1967.

${ }^{11}$ Roi examined classical behaviorism under five aspects: objectivism, S-R orientation, peripheralism, associationism, and environmentalism. 
offer education, but that Ryle's concept of mind combined with Taylor's interpretation of purpose ${ }^{12}$ would provide teachers with a better model for thinking about what they were doing in the classroom. Roi acknowledged that as far as he knew, there had been "no empirical evidence gathered in any systematic way about the way or ways in which teachers think and talk learning or about students as learners, let alone evidence as to whether it makes any difference in their success in teaching." 13 But, he continued, "[i]t is obvious that they must do this thinking and talking with some sort of language ... using certain sorts of concept." 14 He presumed that the conceptual scheme he would argue for would be "better" than other sets because they would enable teachers to teach more effectively than they would have if they had acquired another set of concepts. Roi concluded that the concepts embodied in ordinary language are more adequate to understand classroom contexts than those offered by psychology. For example, "what a teacher will count as "understanding" will vary from one context to another. Thus, ["w] hat . . s seems to be needed in lieu of a precise and well-developed science of psychology is improvement in the precision with which teachers use the relevant terms of ordinary language." 15

Roi played a major role in launching the Association for Values Education Research (AVER). He had noticed the interest in values clarification advanced by Rath, Kirschenbaum, and Simon, but also recognized the need for programs to be grounded in a defensible conception of practical/moral reasoning. From 1976 to 1982, John Andrews was the dean at UBC and had discretionary money at his disposal. He had encouraged a whole range of alternative teacher education programs, so he was receptive to the idea of a centre like AVER. Interdisciplinary work is common these days, but in the early 1970s, it was a novel—even radical—idea. Roi saw an opportunity to build a community of scholars with similar research interests. He became AVER's principal grant writer and, as a former teacher and principal, he had contacts in and credibility with the school community. AVER was formed to study the nature of normative discourse and identify the components of moral competence. Members created and piloted teaching materials ${ }^{16}$ and identified strategies that they hoped would enhance moral development. Members of the association were very productive and influential for nearly ten years. This creative period ended when university funding dried up and a major Social Sciences and Humanities Research Council (SSHRC) grant proposal was not funded.

Roi drove himself hard. In addition to teaching a wide range of courses, supervising numerous theses and dissertations, being the driving force in AVER ${ }^{17}$, and writing grant proposals, he carried heavy administrative responsibilities inside UBC's Faculty of Education. ${ }^{18}$ Jerry Coombs recalls:

${ }^{12}$ Charles Taylor. The Explanation of Behaviour. London: Routledge and Kegan Paul, 1964.

${ }_{13}$ Intervening Variables and Education, op. cit., 13.

${ }^{14}$ Ibid.

15 Ibid., 294. Not surprisingly, Roi made good use of the works of J.L. Austin, T.F. Green, P.H. Hirst, B.P. Komisar, J.E. McClellan, R.S. Peters, and I. Scheffler.

16 They developed teaching materials for promoting moral development under titles such as Elderly (1978), Prejudice (1978), War (1979), Ecology (1980), Population Problems (1980), Prisons (1981), Peace: In Pursuit of Security, Prosperity, and Justice (1991). All were published by OISE Press. Later, AVER broadened its scope to include other subjects-law and Charter education materials, for instance-and developed ties with members of the law faculty and made connections with the prison system.

${ }^{17}$ For three accounts of the work of AVER, see: Murray Elliott. "The Work of the Association for Values Education and Research." CSSE Bulletin 4.2 (1975); Ian Wright, "Value/Moral Education in Canada: The Work of AVER." Journal of Moral Education 6.1 (1976): 32-35; John Meyer, Brian Burham, and John Cholvat. Values Education: Theory, Practice, Problems, Prospects. Waterloo, ON: Wilfred Laurier University Press, 1975.

${ }_{18}$ For example, he was Associate Director, Graduate Studies in Education (1978-1979), Director of Graduate Studies in Education (1980-1983), Head of Social \& Educational Studies (1986-1987), Director of the Centre for the Study of Curriculum \& Instruction (1983-1990) and, when he retired from UBC, he became Coordinator of The Critical Thinking Cooperative in 1995. 
Throughout the early years of AVER, Roi was our administrative leader. When his other administrative duties in the College of Education got too heavy, we decided to choose a new director for AVER. But we needn't have bothered because we kept getting memos from Roi suggesting new projects, calling new meetings, and the like. Finally, I told the other members of the group we either had to make Roi director again or break his hands to keep him from writing memos. Nothing less would stop him.

Near retirement, Roi embarked on his most ambitious and successful effort to promote reasoning in classroom practice. Roland Case, once Roi's doctoral student who later became a colleague and close friend, recounts how The Critical Thinking Consortium was founded:

Although there were countless antecedent events, the "defining moment" was an open meeting of interested scholars at UBC on February 22, 1993. The topic of discussion was a then recent "experts report" on the nature of critical thinking. For at least four participants-Jerrold Coombs and LeRoi Daniels from UBC, and Sharon Bailin and me from SFU, the meeting crystallized the need for a sound and coherent way of talking about critical thinking that would be accessible and pedagogically useful to teachers across the curriculum and spanning all grade levels. The four articulated a conception of critical thinking developed around three key notions:

- Critical thinking is not a generic operation, but must occur within meaningful contexts that should be problems or challenges embedded in the curriculum.

- Critical thinking is centrally concerned with developing sound judgment.

- Thinking critically is an ethic or way of life, not a discrete dimension of the curriculum like fractions in mathematics or Ancient Greece in social studies.

Roi led the project to develop the conception of critical thinking that has guided the Consortium's work since 1993. As well, he was instrumental in founding TC ${ }^{2}$ and was a longstanding member of the Board. Upon his retirement from the Faculty of Education at the University of British Columbia, Roi served as the Consortium's first coordinator and was senior editor of our publications... In honour of his contributions to $\mathrm{TC}^{2}$, we created in 2001 the L.B. Daniels Award for excellence in promoting understanding and implementation of critical thinking, and in 2008 Roi was appointed Director Emeritus. ${ }^{19}$

In his published work, Roi was always thorough in his research, balanced in representing the views of others, critical of misconceptions, and constructive in presenting alternative positions. Much of his best work was done in jointly written articles. Three of the most significant concerned the value of conceptual analysis in educational theory and practice and the nature of critical thinking in the curriculum.

"Philosophical Inquiry: Conceptual Analysis"20, co-authored with his colleague and friend Jerrold Coombs, provides a clear and comprehensive statement on what analytical philosophy can contribute to curriculum development and educational discourse generally. Twenty years after its publication, it remains a definitive statement on the nature and value of analytical philosophical inquiry in education that

${ }^{19}$ Roland Case. Retrieved May 30, 2011 from the Consortium's website:

http://www.tc2.ca/wp/consortium/history/. The work of the cooperative has gained considerable attention since its initial conception in 1993 through the efforts of The Critical Thinking Consortium called TC ${ }^{2}$. It is a nonprofit association comprised of 30 British Columbia school districts, faculties of education, and other educational organizations. This group has worked with approximately one-third of the provincial teaching population—and several thousand educators nationally and in the United States, England, and Israel.

${ }^{20}$ In Forms of curriculum inquiry edited by Edmund C. Short (Albany, NY: State University of New York Press, 1991, 27-42). 
...comprises a diverse set of analytic questions, techniques, and procedures ... that aim at understanding and improving the sets of concepts or conceptual structures in terms of which we interpret experience, express purposes, frame problems, and conduct inquiries. It is an important part of all curriculum research because the conceptual structures we possess determine the kinds of curriculum policies we can entertain and the kinds of empirical and normative research questions we regard as significant. If our conceptual structures lack logical coherence, blur important distinctions, or create useless dichotomies, or if we understand them so poorly that we are unable to translate them adequately into research instruments and policy prescriptions, curriculum policies and research studies will fail to be fruitful. ${ }^{21}$

Under three headings-conceptual interpretation, conceptual development, and conceptual structure assessment - they spelled out the sorts of tasks involved and the value in undertaking them. As a teaching piece for the uninitiated, it is exemplary.

In a pair of articles 22 , Roi and his co-authors defended a conception of critical thinking that served as the theoretical and practical foundation for The Critical Thinking Consortium. They began by analyzing three widely-held conceptions of critical thinking-following a particular procedure, using specific mental processes, and employing certain skills. Each view is, they contended, wrong-headed, misleading or, at best, unhelpful. Apart from the errors or inadequacies of the conceptions themselves, they were likely to promote or abet misconceived practices for teaching critical thinking. They criticized the notion that critical thinking involves generic operations that can be learned in themselves apart from particular knowledge domains and then transferred to, or applied in, different contexts.

They set out to lay the groundwork for a new and better conception based on different foundational assumptions - one that "provides a firm foundation for the development of curricula and programmes for teaching critical thinking." 23 They argued that critical thinking is essentially a normative notion - that is, "critical thinking is in some sense good thinking. It is the quality of the thinking, not the processes of thinking, which distinguishes critical from uncritical thinking." 24 Furthermore, tasks such as problem solving and decision making are "best seen as arenas in which critical thinking should take place rather than as other kinds of thinking to be contrasted with critical thinking." 25 They concluded that "[t]hose who become critical thinkers acquire such intellectual resources as background knowledge, operational knowledge of appropriate standards, knowledge of key concepts, possession of effective heuristics, and of certain vital habits of mind." 26 They thought that "teaching critical thinking is best conceptualized not as a matter of teaching isolated abilities and dispositions, but rather as furthering the initiation of students into complex critical practices that embody value commitments and require the sensitive use of a variety of intellectual resources in the exercise of good judgment." 27 Shades of Paul Hirst!

Roi had life-long professional and philosophical commitments. He had a rare capacity for utilizing philosophy to improve classroom practice. He constantly illuminated the values dimensions of education. He respected ordinary language in education discourse and valued conceptual analysis as a useful philosophical undertaking. He battled constantly against superficial panaceas and the oversimplification of educational issues. And he was forever defending a robust conception of rationality in the development of curriculum materials and classroom practice.

\footnotetext{
21 Ibid., 27.

22 Sharon Bailin, Roland Case, Jerrold R. Coombs, and Leroi B. Daniels. "Common Misconceptions of Critical Thinking" and "Conceptualizing Critical Thinking". Journal of Curriculum Studies, 31.3. 1999. 269-283 and $285-302$.

23 "Conceptualizing Critical Thinking," op.cit., 286.

${ }^{24}$ Ibid., 288.

25 Ibid., 288.

${ }^{26}$ Ibid., 286.

${ }^{27}$ Ibid., 298.
} 
Roi had remarkable success with his graduate students. One of them, Deborah Court, 28 offered this account of Roi's role as her supervisor.

I first met Roi Daniels in the spring of 1986 when he interviewed me for the doctoral program in the Centre for the Study of Curriculum and Instruction at University of British Columbia. He began by saying, "I read your Master's thesis and [with some sarcasm] it was okay, but nothing special. Tell me why we should accept you into the doctoral program." I then produced an impassioned argument as to why "just a teacher" should be accepted and given a chance to blossom.

When I was accepted, Roi became my doctoral advisor and under his tutelage I discovered intellectual capabilities that had long lain dormant. Roi was a brilliant advisor-critical, supportive, demanding of hard work, funny, scrappy, and big-hearted.

At my doctoral defense, he asked me astoundingly difficult, critical, and obtuse questions. Afterwards while being treated to a drink at the faculty club but feeling as limp as a dishrag, I asked him why he had posed such difficult questions. "I thought you were supposed to support me," I said slightly wounded. "I wanted to show you off," he replied proudly.

Roi never shied away from an intellectual challenge or a conceptual skirmish. He tried to pass on his passion for conceptual astuteness. Through Roi, graduate students discovered Gilbert Ryle, Wittgenstein, and Polanyi, learned how to think conceptually, and how to analyze language. We learned that "writing is thinking", something he said repeatedly, and something I often say now to my own graduate students... His sharp, critical mind, boundless energy, and generous heart made him a giant. He was the biggest single intellectual influence in my life, and I'm sure many, many former students would say the same.

Anecdotes about Roi are legion. He could be pugnacious, blunt, funny, stubborn, generous, tireless, but always philosophically passionate. On one occasion at a Northwest Philosophy of Education meeting, a philosophy professor talked about the mind as though it were located in the skull. Roi baited him telling him that his (Roi's) mind was in his leg. The guy thought Roi must have been joking! Roi was so keen that people understand the concept of mind apart from psychology and the brain. At a CSSE conference, I recall Roi maintaining that "thirst" was an emotion. This resulted in a raucous discussion: Was an itch an emotion? What about a sore throat? A tickle? A twitch? Roi remained adamant. When I reminded him of this exchange last year, he scoffed at himself for ever having thought such an outrageous thing and we laughed heartily! Jerry Coombs relates an incident when they were both in Ottawa seeking funding (Roi was always looking for funding!). Roi had agreed to put on a workshop at a school in a "nearby" city the day after meeting with the funding agency. Roi always read "conceptual maps" with great care, but road maps? Not so much! Very late at night after an evening of tippling and making plans for future funding talks, Roi decided to find out how to get there. As it turned out, the "nearby" city was some two hundred miles away, so Roi set off about 3:00 a.m. to honour his commitment!

Though Roi could be sharply critical, he could also be very generous when he thought something was worthy of praise. Take, for example, his review of Sharon Bailin's Achieving Extraordinary Ends: An Essay on Creativity (1988):

This is a fine book. It offers a systematic, exhaustive, and devastating critique of the view of creativity most popular in education today.... Contrary to the popular view, creativity concerns

\footnotetext{
${ }^{28}$ Dr. Deborah Court (Ed.D., UBC, 1988) is currently a senior lecturer in the School of Education, Faculty of Social Sciences, Bar-Ilan University, Ramat-Gan, Israel. Her dissertation was entitled, "A Critical Analysis of Personal Practical Knowledge" (1988).
} 
not one or more so-called "processes"; rather it is about products that are or help us achieve extraordinary ends... the book not only offers a powerful argument for a conception of creativity but is itself an exemplar of what Bailin deals with. It is a creative use of philosophy to clarify an important concept. ${ }^{29}$

Roi endeared himself to his colleagues across Canada. Doug Stewart remembers Roi "as a perennial and engaging presence at CPES, contributing his wisdom and wit to proceedings and social gatherings alike. He once said that of all the conferences he attended, the CPES/CSSE ones were his favourite!" Harold Entwistle enjoyed Roi's capacity for collegiality and friendship. Paul O'Leary recalls "his sharp and intelligent questioning as well as his abundant good nature." Bill Hare remarked on Roi's generosity: in 1993 when he was teaching summer school at UBC, Roi loaned him his car to drive his family to Victoria for the weekend!

Charles Brauner, who worked with Roi in UBC's Faculty of Education for more than forty years, remembers:

LeRoi was a good friend, a fine colleague, and a devoted academic. His love of ancient and modern philosophy knew no bounds. He found moral inspiration in the works of Plato and Aristotle as well as subtlety and wisdom in linguistic analysis. Yet he never ridiculed others for their mistakes, or sought advantage at someone else's expense. He had the gift of simplifying the complex and explaining the difficult with an enthusiasm that made him an excellent teacher. I never tired of his companionship or lost interest in his observations. He was a true companion to all who knew him.

Jerrold Coombs comments on his enduring relationship with Roi:

I was privileged to have Roi as my closest friend, colleague, and academic collaborator at UBC for many years. John Dewey claimed that learning is central to living. No one embodied that view of the good life better than Roi. He was a voracious reader with wide ranging interests, and despite holding a variety of administrative positions during his career, he always managed to keep a hand (and his heart) in some academic research project. To every project, Roi brought not only considerable philosophical acumen, but also enormous energy, enthusiasm, and good humour. Colleagues and students fortunate enough to work with him found him generous with his time, support, and praise for their contributions. Roi loved a good argument, and although he could be fierce in representing his views, he was always willing to change them when given good reasons to do so. He was, in many ways, the quintessential critical thinker.

In bidding farewell, Roland Case, a younger colleague and co-founder with Roi of The Critical Thinking Cooperative $\left(\mathrm{TC}^{2}\right)$, paid a special, very personal tribute:

On April 1st, TC ${ }^{2}$ lost a great champion and I lost my mentor and dear friend... Roi embodied some of the finest human virtues: a tireless commitment to any noble cause, a generous and compassionate heart, and a wise and witty intellect. ${ }^{30}$

Roi had that sort of affect on people.

\footnotetext{
${ }^{29}$ Canadian Journal of Education 16.1 (1991): 166-17.

30 Roland Case. "In Memorium: LeRoi Brian Daniels, 1930-2011.” Teaching Critical Thinking Consortium. Web. 30 May 2011. < http://www.tc2.ca/wp/>
} 


\section{Works That Significantly Influenced His Thinking}

Benn, Stanley I. and Richard S. Peters. Social Principles and the Democratic State. London: Allen and Unwin, 1959.

Dewey, John. Democracy and Education. New York: The Macmillan Company, 1936.

Flathman, Richard E. The Practice of Rights. Cambridge and New York: Cambridge University Press, 1976.

Kant, Immanuel. Groundwork of the Metaphysics of Morals. New York: Harper Torchbooks, 1964.

Kohlberg, Lawrence. Essays on Moral Development, Vol. I: The Philosophy of Moral Development. San Francisco: Harper \& Row, 1981.

Leiser, Burton M. Custom, Law, and Morality. Garden City, NY: Doubleday and Co., 1969.

Ryle, Gilbert. The Concept of Mind. London: Hutchinson's University Library, 1949.

Smith, B. Othanel and Milton Meux. A Study of the Logic of Teaching. Urbana, IL: University of Illinois Press, 1970.

Taylor, Charles. The Explanation of Behaviour. London: Routledge and Kegan Paul, 1964.

Taylor, Paul. Normative Discourse. Englewood Cliffs, NJ: Prentice-Hall, 1961.

White, Alan R. The Philosophy of Mind. New York: Random House, 1967.

Wittgenstein, Ludwig, Philosophical Investigations. Oxford: Blackwell, 1958. 